\title{
VIAGEM TEXTUAL PELO SUL GLOBAL: IDEOLOGIAS LINGUÍSTICAS QUEER E METAPRAGMÁTICAS TRANSLOCAIS
}

\author{
Luiz Paulo da Moita Lopes* \\ Branca Falabella Fabrício** \\ Universidade Federal do Rio de Janeiro \\ Centro de Letras e Artes \\ Faculdade de Letras \\ Rio de Janeiro, RJ, Brasil
}

\begin{abstract}
Resumo: Com base na análise da reentextualização de um vídeo profissional brasileiro de funk em um vídeo caseiro nas Filipinas, feito por meninos queer, este artigo discute a ideologia linguística e as projeções metapragmáticas translocais que tal trajetória textual enseja. Pautado em teorizações queer, o trabalho explora essa movimentação translocal utilizando os construtos teórico-analíticos de indexicalidade, circulação de discursos, campos de comunicabilidade e performatividade. Argumenta que a ideologia linguística mobilizada no processo de reentextualização focalizado diferencia-se das tradicionais ideologias linguísticas representacionais e modernistas, ao apontar para visões performativas de línguas e dos corpos dos participantes. Tal ideologia é forjada por meio de metapragmáticas translocais que projetam uma lógica de um mundo social como-se. Investigá-la implica a observação de indexicalidades-em-movimento.
\end{abstract}

Palavras-chave: Reentextualização. Indexicalidade. Ideologia linguística. Translocalidade. Teorias queer.

A ressignificação do discurso requer a abertura de novos contextos, falar de modos que não não foram ainda legitimados e, portanto, produzir legitimação de maneiras novas e futuras.

(Judith Butler)

\section{GLOBALIZAÇÃO, FLUXOS NO "SUL GLOBAL" E O INESPERADO SURGINDO AQUI E ALI}

A globalização tem sido explicada, em grande parte, pelos fluxos "de objetos, pessoas, imagens, e discursos" (APPADURAI, 2001, p.5). Se partirmos da ideia de que "a vida humana é baseada em e no movimento" (THRIFT, 2008, p.5), os trânsitos globais contemporâneos poderiam ser caracterizados como a intensificação dessa mobilidade inerente à própria existência. A celeridade, possibilitada pelos avanços tecnológicodigitais, provoca, segundo Appadurai (2001, p. 6), instabilidades e reagregações

\footnotetext{
* Programa de Pós-Graduação Interdisciplinar em Linguística Aplicada da Universidade Federal do Rio de Janeiro. ORCID: <https://orcid.org/0000-0002-3829-9824>. E-mail: moitalopes@ oi.com.br.

** Programa de Pós-Graduação Interdisciplinar em Linguística Aplicada da Universidade Federal do Rio de Janeiro. ORCID: < https://orcid.org/0000-0003-0006-9924>. E-mail: brancaff@ globo.com.
} 
constantes. Por um lado, os fluxos crescentes promovem disjunções, i.e., "problemas de subsistência, equidade, sofrimento, justiça, e governança" por causa dos desequilíbrios que ocasionam quando encontram realidades sociais depauperadas e contrastantes. Por outro, os deslocamentos incessantes arrastam uma profusão de discursos que, atravessando vidas locais, podem tornar as pessoas conscientes de outras alternativas para elas mesmas. $\mathrm{O}$ autor se refere a essa segunda característica como mobilizadora do "papel da imaginação na vida social" (p. 6). Imaginar a vida social local diferentemente talvez seja o grande desafio que a dita globalização possibilita, ao nos situar cada vez mais translocalmente em meio a significados inovadores, criando, assim, oportunidades de confrontar novos sentidos. Tal enfrentamento é potente pois, ao promover o contato de repertórios diversos, pode forjar, na fricção, novos valores, pensamentos e desenhos sociais (FABRÍCIO, 2014, 2018). Pode rearranjar também credos arraigados sobre "língua", linguagem e comunicação - ponto de interesse deste artigo.

Exercícios de imaginação estão em ação cotidianamente, mas, no momento atual, eles se apresentam na web de forma bastante vigorosa. Devido à sua capacidade de colocar textos em circulação, ambientes digitais possibilitam descentramentos textuais incessantes, ao replicarem-recriarem textos em velocidade sem precedentes. Fenômenos virais na internet são indicativos desses movimentos contínuos de (re)apropriações criativas como, por exemplo, a propagação pelos quatro cantos do planeta de vídeos filipinos nos quais um grupo de meninos $^{1}$, ao estilizar divas da cena hip-hop contemporânea, subvertem toda sorte de normas e padrões e improvisam outros modos de existência para "línguas", textos, sentidos e corpos.

Royce Cherdan Lee é o líder do grupo de dançarinos amadores conhecido como Team ASPO. Residente na ilha Cebu, nas Filipinas, produz e publica semanalmente vídeos caseiros nos quais imita-dubla-coreografa, ao lado de amigos coadjuvantes, deusas da música pop de diferentes regiões do globo. As estadunidenses Beyoncé e Megham Trainor e as brasileiras Valeska Popozuda e Anitta são algumas das musas que fazem parte de seu repertório. As performances viralizaram na Internet a partir de 2014, tendo sido vistas em várias partes do mundo por mais de três milhões de pessoas. Realizadas com poucos recursos e em condições precárias, as produções do Team ASPO assumem a vulnerabilidade como ponto de partida para suas (re)criações. A pressuposição da fragilidade leva os integrantes do grupo a lidar com o imprevisto, o erro e o inesperado, inerentes a qualquer realização, de forma rotineira, sem a preocupação de repará-los. Operam segundo uma outra lógica. Não a lógica do fracasso da imitação, mas sim, a lógica do "como-se", i.e. a lógica da mímica que se assume como tal e que, sem apelar para subterfúgios, se reinventa. Butler (1997, p. 68) se refere a tal lógica, argumentando que, ao invocarmos o "ser" - em formulações do tipo "alguém/algo é" -, o que fazemos é projetar a ideia de "como se alguém/[algo] fosse". Em outras palavras, expressamos uma alegoria. Nela, por exemplo, pedaços de madeira viram metralhadoras, tijolos amarrados aos pés simulam sapatos de salto alto, um bote rústico vira o transatlântico Titanic. Da mesma forma, meninos franzinos de bermuda, chinelo e camiseta encenam damas glamorosas e sensuais. Assim, podemos dizer que, na "zona de contato" (PRATT,

\footnotetext{
${ }^{1}$ Disponível em < https://www.facebook.com/TeamASPO/videos/608901775921485>. Acesso em: 4 fev. 2015.
} 
1987), esses artistas filipinos produzem paródias de celebridades musicais, transformando, com muito humor e ludicidade, as produções profissionais originais em algo novo.

Neste trabalho argumentamos que as performances artísticas do Team ASPO possibilitam o questionamento de uma ideologia linguística modernista, desconhecedora da mobilidade da vida social porque capturada por ideiais de estabilidade, pureza e autonomia. A este trio se associam visões essencialistas de língua, gênero, raça, sexualidade, classe social e nacionalidade, nas quais corpo e língua existem em separado. Os Team ASPO cruzam múltiplas fronteiras (MIGNOLO, 2000) e, ao fazê-lo, desalojam, queerizam ${ }^{2}$ e reinventam as chamadas "vozes da modernidade" (BAUMAN; BRIGGS, 2003). Também colocam em xeque o projeto histórico gigantesco chamado de Ocidentalismo (VENN, 2000), um ideal modernista, iniciado no final do século XV. Como um conceito socio-histórico-político e econômico, o chamado ocidente, ao imaginar a projeção dicotômica de hemisférios - norte e sul - e de relações de cima para baixo entre países, investiu na meta de levar o que era construído como ocidente para outras partes do mundo. Tais ambições continuam a florescer na forma do velho globalismo ou globalitarismo ocidentalista (SANTOS, 2000) em uma globalização de cima para baixo, ou na direção convencionalizada norte-sul, particularmente no mundo dos fluxos do capital e da indústria cultural. Estes últimos ganham mesmo um fôlego estupendo em nossas sociedades contemporâneas rentistas e ultraliberais.

Contudo, os fluxos de pessoas e discursos na direção "sul-norte" - ou mesmo na direção "sul-sul", como mostram nossos dançarinos filipinos - têm se acentuado nas últimas décadas, para além do atravessamento de fronteiras entre estados colonizadores e antigas colônias, tipicos do século XX. Tal movimentação vem construindo um tipo diferente de globalização em termos de fluxos de pessoas, culturas, recursos semióticos e discursivos etc. Trânsitos de pessoas e objetos sempre existiram. No entanto, eles são mais abundantes agora em face das tecno-inovações globalizadas, garantidoras de locomoção rápida no tempo-espaço físico e digital.

Os intercâmbios culturais por meio da web têm sido extremamente impactantes embora haja ainda uma predominância do padrão da velha ocidentalização do mundo, particularmente por meio das TVs a cabo e aberta. Nesses espaços, podemos considerar os Estados Unidos como dando sequência a esse processo histórico de ocidentalização na direção que se toma como norte-sul, ao inundar múltiplos espaços com artefatos culturais (musicais e cinematográficos, por exemplo). No entanto, o espaço digital possibilitou a navegação por fluxos culturais por quase todo o mundo independentemente de suas origens. Qualquer um, de sua própria casa, com um pequeno celular, pode, ao produzir e postar artefatos culturais de lugares considerados 'periféricos' (MOITA-LOPES;

\footnotetext{
${ }^{2}$ Queerizar é um termo advindo do que se convencionou chamar de teorias queer. O termo queer é ainda utilizado em muitos círculos de forma derrogatória para ridicularizar homens gays, mas foi apropriado e ressignificado pelas chamadas teorias queer, como um verbo, para desconstruir significados modernistas, binários e essencializados de gênero e sexualidade. A lógica queer é a da instabilidade, da desessencialização, da desnormalização, da ficção performativa e do "passar por" ou a lógica do "comose", que será aprofundada posteriormente. O livro de Butler (1990) é considerado a mola propulsora de tal teorização ao problematizar "a matriz heterossexual" que nos orienta, fazendo-nos passar por homens ou mulheres e por heterossexuais ou homossexuais.
} 
BAYNHAM, 2018), alcançar qualquer região do planeta. Royce e seus amigos são um exemplo eloquente dessas práticas, nas quais postagens na web cumprem trajetórias inesperadas. Pode-se dizer que a circulação célere e imprevisível desses textos lança o/as interlocutores em meio à multidão (HARDT; NEGRI, 2005): de pessoas, desejos, "línguas" e diferenças.

Embora a multidão esteja, de muitos modos, ainda fluindo nas direções "norte-sul" (e vice-versa), que eram típicas do antigo modo de ocidentalização (VENN, 2000), os processos de circulação contemporâneos são, cada vez mais, multidirecionais. A errância e a multiplicação de acasos são constitutivas de nossas sociedades superdiversas (VERTOVEC, 2007), nas quais todos os tipos de coisas (artefatos culturais, discursos e recursos semióticos de toda natureza) estão surgindo em lugares impensáveis (PENNYCOOK, 2012), reimaginando as rotas tradicionais "norte-sul", ao fluírem em direções rizomáticas, que não podem ser previstas. Em uma perspectiva similar, mas tratando especificamente sobre "línguas", que constituem outro interesse nosso aqui, Heller (2007, p. 343) indica que " tão logo comecemos a olhar mais de perto [o que está acontecendo] ... vemos movimento. Vemos línguas aparecendo em lugares inesperados [...] tomando formas inesperadas".

São essas circunstâncias que nos motivam a explorar como os Team ASPO reentextualizam nas Filipinas artefatos culturais disponibilizados no YouTube, dentro de um padrão de fluxos que atravessa o chamado sul global. Em especial, focalizamos a translocalização do funk brasileiro "O Show das Poderosas" cantado em "português" por Anitta e encenado, também em português, pelo grupo filipino. A cantora - uma popstar do funk brasileiro atual cujos vídeos também viralizaram na internet - performa uma feminilidade heterossexual. Em contraste, a recriação realizada pelos meninos produz um pastiche queer que golpeia visões essencializadas de "língua", linguagem e "identidades sociais". Nosso foco de interesse é compreender como se dá tal prática de reentextualização ou ressemiotização que tomamos como possibilidade de abordar "língua", linguagem e subjetividades segundo processos de imaginação ou de "como-se".

Para desenvolver tal objetivo hibridizamos as reflexões propiciadas pelos funkeiros filipinos e aquelas produzidas por teórico/as que questionam a episteme modernistacolonialista.

\section{CIRCULAÇÃO DE DISCURSOS}

Alinhados a uma visão de mobilidade, Bauman e Briggs (1990) sugerem que textos - como agregados de signos - só podem ser compreendido por processos contínuos de entextualização-descontextualização-recontextualização por meio dos quais vamos reciclando textos ou fragmentos de textos que legitimamos como adequados aos processos de construção do significado. Um tal processo sugere que textos não são confinados a nenhum espaço específico. São continuamente deslocados de um ambiente semântico e reentextualizados/ressemiotizados em outro (SILVERSTEIN; URBAN, 1996). Nessa transposição textual, algo novo sempre acontece, indicando que toda repetição implica simultaneamente uma transformação. Assim sendo, o que pode parecer 
mera duplicação sempre contém algum nível de adaptação a novos ambientes interacionais - pelos quais circulam outros textos, outros discursos, outros interagentes, outras espacialidades-temporalidades, não determináveis a priori. De acordo com essa perspectiva, trajetórias textuais contam necessariamente com contingências e casualidades, tornando as recontextualizações acontecimentos intertextuais imprevisíveis, pois ao mesmo tempo que iteram, citam e copiam outros textos, os transformam em diálogo com circunstâncias emergentes. É esse tipo de circuito que performativamente constrói significados sempre em movimento. A suposta mímesis, como aponta Pennycook (2010), nunca é perfeita, o que se aplica ao próprio objeto mimetizado, ele mesmo uma réplica de uma réplica de uma réplica ... ad infinitum. Ao contrário, a imitação é reprodução criativa, fazendo das ideias de estabilidade e originalidade ilusões performativas - uma lógica que dialoga com as teorizações queer (ver nota 3).

Inúmeros autores de nossa tradição filosófica enfatizam a diferença, repetição, intertextualidade e fluidez como características dos processos de significação (DELEUZE, 2004/1968; DERRIDA, 2013/1967; BAKHTIN, 1981, por exemplo). Refutam, portanto, a ideia de contexto original de produção discursiva, em favor da visão de textos em diálogo contínuo com outros textos. Entretanto, em nosso mundo dos fluxos, outro/as estudioso/as têm focalizado a exacerbação dramática dos processos de entextualização-descontextualização e reentextualização, como por exemplo, trajetórias textuais virais (VARIS; BLOMMAERT, 2014). A viralidade é por ele/as abordada como sendo criadora de públicos específicos (BRIGGS, 2007) e de um sentido de "pertencimento de grupo" (VARIS; BLOMMAERT, 2014, p. 6), ao recrutar performatividades identitárias de interlocutore/as. Tais aspectos podem ser elucidados se tomarmos o caso do "Show das Poderosas"3 como elemento de interrogação, por um momento.

O vídeo oficial estrelado por Anitta é uma produção na qual a cantora, acompanhada por um grupo de dançarina/os, canta e dança o funk de sua autoria "Show das Poderosas" em um estúdio. O trabalho é profissional, envolvendo direção e planejamento sofisticados de iluminação, maquiagem, figurino, adereços, coreografia, sincronia, som, enquadramento e edição. A letra em português (conferir Anexo 1) trata de garotas poderosas que provocam inveja por seus corpos e estilo sedutores. Elas são tão espetaculares e competitivas que relegam outras meninas à invisibilidade. Sua dança é sensual, se desenvolvendo dentro de uma "matriz heterossexual" (BUTLER, 1990), mas que é perturbada pela presença de alguns dançarinos que também performam as poderosas, seguindo, de forma impecável, a movimentação corporal de Anitta.

$\mathrm{Na}$ imaginação dos dançarinos filipinos, em contraste, "as poderosas" realizam seu show em uma outra paisagem semiótica. Ele é transposto para uma praia entulhada de objetos (carros, barcos, botes, lixo etc.), indicando um espaço em estado de pobreza material. Esse cenário não idealizado - e não higienizado, por assim dizer - é cheio de obstáculos que vão sendo incorporados à performance, modificando os passos do show

\footnotetext{
${ }^{3}$ Disponível em <https://www.youtube.com/results?search_query=anitta+show+das+poderosas>. Acesso em: 25 jan. 2017. 
inspirador. Um carro, por exemplo, pode virar uma barra de balé (ver Figura 1 abaixo). A buzina de um navio que passa é aproveitada para marcar o início do "show". A indumentária se reduz a roupas de uso diário. Royce de alguma forma mimetiza o "português do Brasil", mas seus movimentos labiais na dublagem não chegam a sincronizar com a letra da música cantada por Anitta, que anima a performance. Em uma primeira visada, a mímica pode ser percebida como falha e cheia de contratempos. Percebe-se que houve algum tipo de ensaio, mas com uma direção frouxa. Entretanto, observando outras atuações do Team ASPO, nota-se que o grupo não tem por hábito se comprometer com repetições exatas dos movimentos de suas inspiradoras, como Anitta, nem corporais nem tampouco linguísticas. A preocupação dos artistas não é com a cópia, mas sim com a renovação de um "modelo" que incorpora elementos semióticos (somáticos e não-somáticos) emergentes ao longo da encenação.

\section{Figura 1 - Captura de tela do vídeo "Show das Poderosas" entextualizado pelo grupo Filipino Team ASPO}

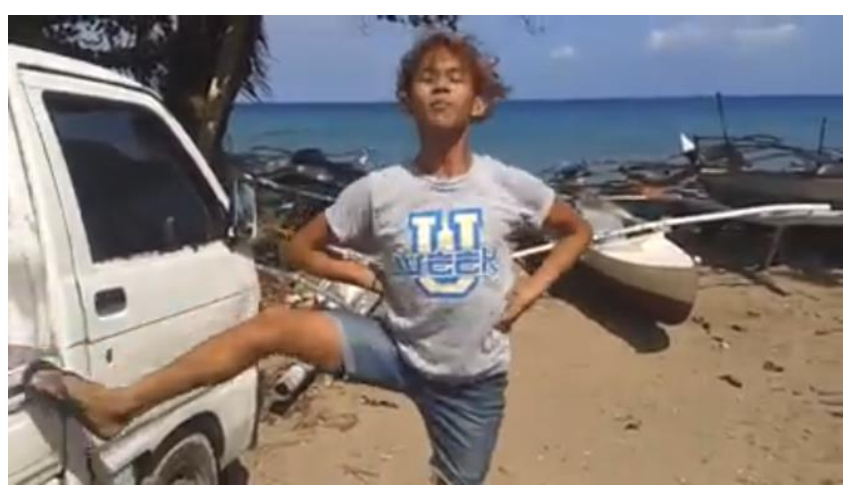

Todos esses aspectos ajudam a queerizar ou desnormalizar expectativas sedimentadas sobre vídeos artísticos em circulação. É preciso considerar o imponderável. Por um lado, as circunstâncias de produção das poderosas filipinas indiciam precariedade de recursos; por outro, indexam a experiência queer propiciada por artefatos culturais que circulam na web, incluindo cantar em "língua portuguesa". Além disso, propiciam uma reflexão sobre linguagem e comunicação. A dessincronização dos lábios de Royce desessencializa não apenas o que entendemos por "português do Brasil", mas também tudo aquilo que denominamos "língua" tradicionalmente. Em suas performances a "língua" imitada é sempre um fenômeno "como-se" no sentido de que projeta uma ilusão de unidade, homogeneidade e essência que ganha existência em práticas performativas (PENNYCOOK, 2007; MAKONI; PENNYCOOK, 2007). Dessa forma, o "português" de Royce é um tipo possível de "português brasileiro" (como é sempre inevitável que o seja!), revozeado com movimentos labiais "incorretos" ou "repentinos", que sugerem o efeito do que chamamos "português do Brasil". Na sua performance drag, corposmeninos se confundem com corpos-meninas, uns passando pelos outros, (assim como transitamos performativamente por referências identitárias normalizadas, ora referendando-as ora transgredindo-as). Do mesmo modo, o "português", como ficção performativa que é, passa sempre por "português". Royce não investe em ir além dessa sugestão. Acompanhando seu gesto, entendemos que a entidade que nomeamos 
“português” é na verdade um 'passar por' que se sedimenta em práticas de normalização daquilo que se considera "o português" do Brasil. O jogo "como-se" seria, assim, constitutivo de nossas ações semióticas (linguísticas e não-linguísticas), de quem somos e das formas de comunicação (ver MOITA-LOPES, 2018).

O grupo nos convida, então, a projetar um outro território de significação onde a experimentação com signos e jogos semióticos prevalecem sobre a repetição de lances normalizados, materializando a percepção de Thrift sobre linguagem (2008, p.7) de que as ações de brincar/jogar devem ser entendidas como "atividade humana perpétua". Nesse cenário, os jogadores-dançarinos driblam as adversidades com criatividade e imaginação e, ao fazê-lo, brincam com as possibilidades do "se" ou do mundo "como -se".

\section{CIRCUITOS DE COMUNICABILIDADE E A PERFORMATIVIDADE DO MUNDO "COMO-SE"}

Observando os dançarinos de uma perspectiva interseccional (SULLIVAN, 2003; BARNARD, 2004; TAYLOR, 2016), podemos dizer que os meninos estão encenando pertencimento a uma comunidade carente do sudeste da Asia, seja lá o que isso signifique em termos étnico-raciais. É possível também perceber que suas performances perturbam performatividades de gênero e sexualidade tradicionais. Eles não se enquadram na matriz heterossexual. Royce, sobretudo, move seu corpo de uma forma inusitada para corpos masculinos. Entretanto, sua roupa é condizente com parâmetros relacionados a homens jovens (bermuda jeans e camiseta). Apesar disso, seu gestual corpóreo estiliza uma "alta performance" (COUPLAND, 2007, p.146) de um corpo estereotipicamente associado a mulheres. O modo como move os braços, projeta os quadris para trás e requebra seus ombros não só indexam estereótipos generificados de sensualidade, mas também tornam o seu corpo "feminino" o foco de atenção. Além disso, a forma como acaricia o cabelo pintado de louro, conjugada com sua expressão facial, indexa erotização e prazer sexual. Ainda como parte dessa "alta performance" estereotipada, ele caminha com passos ritmados que, ao pressionar uma perna contra a outra, escondem qualquer vestígio de um pênis como índice sexual. Sua recontextualização somática do 'Show das ponderosas' investe ainda no meneio do torso-como-se-seios, e do rebolado das nádegas que se viram para as câmeras (ver Figura 2 abaixo). Tal gestual se contrapõe ao dos outros meninos do grupo, que parecem operar mais perto da matriz heterossexual. O contraste, ao lado dos outros índices apontados, constrói o 'acento' queer que guia a produção do vídeo performativamente. É nesse sentido que Shusterman (2000, p.156) argumenta que "práticas somáticas que afirmam transformar nossa experiência corporal, [...], podem ser analisadas em termos de suas pressuposições, efeitos e ideologias". A análise envolve tornar recursos semióticos-em-movimento e indexicalidades-em-movimento como lócus de investigação (FABRÍCIO, 2014 e 2018). 
Figura 2 - Captura de telas do vídeo "Show das Poderosas" entextualizado pelo grupo Filipino Team ASPO
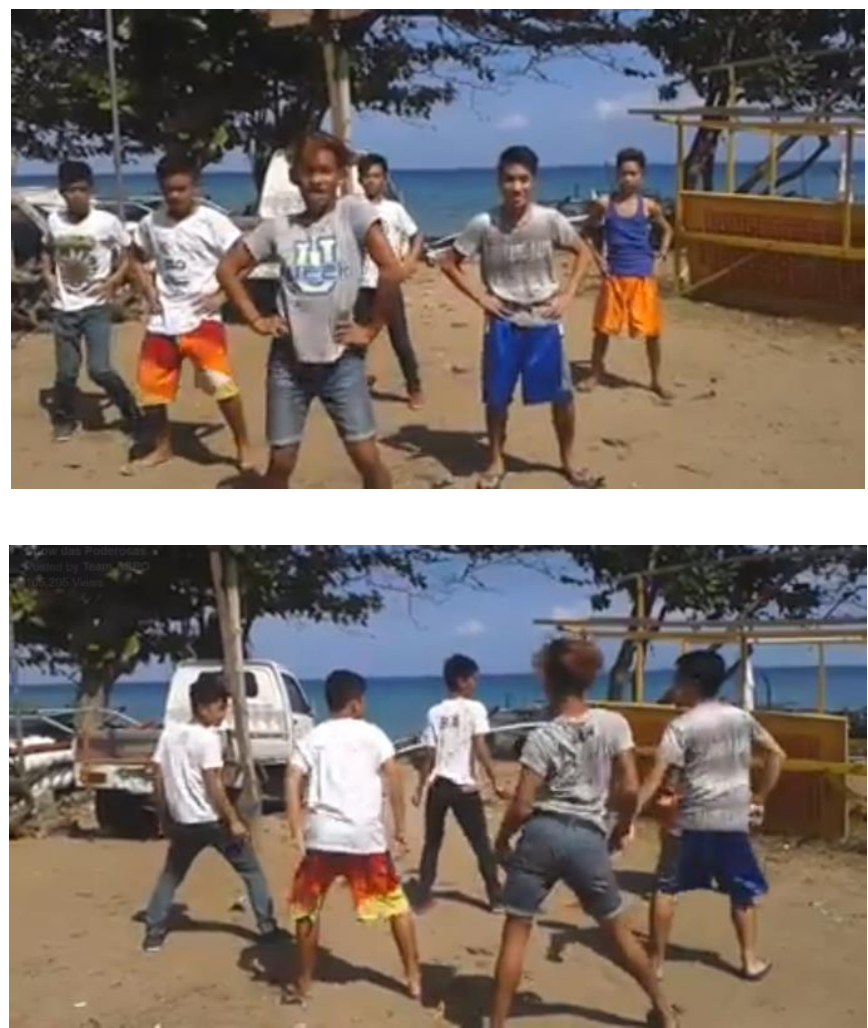

O vídeo de Anitta, ao ser recontextualizado em uma paisagem semiótica diferente, mobiliza novos recursos que indexam outros sentidos. Apesar da produção de Royce conter alguns rastros do vídeo brasileiro (música, letra, alguns passos de dança, sensualidade), ela esgarça os laços com seu "original" devido aos significados queer indexados. Resta lidar, então, com um enigma: a performance de Royce é repetição com transformação ou é totalmente inovadora? Essa pergunta, em si mesma, queeriza a ideia de um suposto vídeo original de Anitta - também uma ilusão performativa de múltiplas recontextualizações. Somos jogados, então, na indecidibilidade. Qual vídeo é o “original” e qual é cópia? O de Anitta? O de Royce? Os dois apenas fazem sentido performativamente "para e perante uma audiência" (COUPLAND, GARRET; WILLIAMS, 2005, p. 69). Em suas trajetórias, os vídeos constroem públicos particulares, não tendo portanto sentidos a eles intrínsecos. Esse é o campo que Baynham (2015) denominou "sociolinguística performativa".

É essa perspectiva performativa que chama a nossa atenção para como a viagem textual do vídeo de Anitta, ao ser reentextualizado nas Filipinas por meninos em performatividades queer, mobiliza outros discursos, interpelando outros públicos. Itinerários dessa natureza podem ser compreendidos pelo que que Briggs (2007, p.556) chama "circuitos de comunicabilidade". Segundo o autor, todo texto é um metatexto, no sentido de que faz projeções metapragmáticas de seu modo de produção, de circulação e de interpelação. Por essa visada, os mapas comunicáveis dos dois vídeos nos conduzem por rotas distintas, mobilizando projeções metapragmáticas diferentes. 
O vídeo de Anitta entextualiza um tipo de funk que, tendo sido comodificado pela indústria cultural, se alinha com a chamada música pop carioca ao afastar-se de um tipo de funk reconhecido como sendo de raiz, batidão, ou de periferia (LOPES, 2011). Como tal, sua produção sofisticada é disponibilizada em rede, projetando um público geral de fãs de uma vertente massificada do funk carioca nos contextos nacional e internacional. A amplitude de circuito e audiência parece orientar o conjunto de escolhas técnicas (arranjos sônicos, figurinos, e movimentos) que tipificam um tipo de performance internacionalizada, facilmente reconhecível em atuações de ícones como Beyoncé e Lady Gaga. Essas alternativas sugerem um tipo de interpelação e impacto estético em concordância com um gosto musical estandardizado. Pode-se dizer, então que o público de Anitta, na fase de sua carreira em que lançou o "Show das poderosas", é unificado pela repetição. Segundo Briggs (2007, p. 555), “os públicos são criados quando os textos os engajam de modos particulares, induzindo-os a se sentirem parte de um grupo social que compartilha uma orientação particular em relação a formas específicas culturais de circulação pública". Entretanto, o autor pondera que, apesar da possibilidade de modelos de comunicabilidade ensejarem uma determinada ilusão de como o texto vai se movimentar e de como será compreendido, nunca podemos garantir circuitos, audiências e modos de afecção. Esses processos só emergem performativa e contextualmente aqui e ali. É assim que o vídeo de Anitta encontra um público inusitado na ilha Cebu: o Team ASPO. O grupo, em sua ressemiotização do vídeo de Anitta invoca outras pragmáticas e metapragmáticas, que podemos chamar de translocais, devido aos seus atravessamentos 'espaciais' em sua circulação (PENNYCOOK, 2010).

A re-encenação das garotas poderosas por Royce e seu grupo na ilha Filipina cria um outro público nos fluxos da globalização, projetando novas possiblidades de interpretação, i.e. novas metapragmáticas. A comunicabilidade em jogo é outra, pois os meninos parecem resistir ao modo de "recrutamento" padronizado esperado pela circulação de realizações midiáticas de massa. As produções caseiras do Team ASPO são semanais, criando um público cativo que se orienta por essa temporalidade. As improvisações que as caracterizam, com rearranjos surpreendentes forjam um enquadre interpretativo de paródia humorístico-crítica que parece "zoar" tanto da tecnologização de produções do show business contemporâneo quanto das imagens estereotipadas que elas fazem circular de gênero e sexualidade. Quando são postadas em rede, antecipam uma circulação que faz a dita periferia navegar por mundos urbanos, possibilitando indagações sobre a discriminação, nas Filipinas e em outros muitos espaços, da chamada "cultura LGBT+".

Além disso, a circulação digital os conduz a um cosmopolitismo do tipo "comose". Por essas lentes, reinterpretam a 'periferia' filipina, transformando-a com seus movimentos corporais queer. Agem, assim, como se praticassem um parkour ${ }^{5}$ marginal,

\footnotetext{
${ }^{4}$ Recentemente, a cantora mudou a orientação da carreira em direção a um retorno às " raízes", como, por exemplo, em produções como "Vai malandra" de 2017, entre outras.

${ }^{5}$ De acordo com definição do "Dicionário infopédia da Língua Portuguesa sem Acordo Ortográfico, parkour significa: "DESPORTO, atividade desportiva cuja inalidade é deslocar-se entre dois pontos, num ambiente urbano ou natural, seguindo um trajecto alternativo, geralmente mais curto e difícil a nível físico. Disponível em: <https://www.infopedia.pt/dicionarios/lingua-portuguesa-aao/parkour>. Acesso em: 15 mar. 2017.
} 
no qual os obstáculos a serem vencidos não são construções de concreto ou rochas, mas sim a precariedade de recursos disponíveis. Ao teorizar sobre os grafites como forma de interferência em ambientes urbanos, Pennycook (2010, p. 60) compara essa forma de arte gráfica ao parkour, ressaltando que a reinterpretação de paisagens tem impacto indentitário nos/as artistas e nos habitantes dos espaços redesenhados. Por esse ângulo, os praticantes filipinos de parkour se recriam, remodelam seu entorno e impactam aquele/as que com eles interagem ao questionarem, em suas performances multisemióticas, modos de comunicação, territorialização, e subjetivação sedimentados.

Perante tal complexidade, qualquer vínculo com uma perspectiva de representação de um real seria improdutivo. O sentido só funciona na relação de corpos, espaços e múltiplos elementos semióticos cujo nexo se encontra no efeito de conjunto emergente e não na correspondência ato/designação, tão cara a uma abordagem modernista e referencial de linguagem. As práticas de imaginação do Team ASPO também nos auxiliam a relocalizar essa tradição.

\section{A NATUREZA INVENTADA E PERFORMATIVA DAS "LÍNGUAS": UMA OUTRA IDEOLOGIA LINGUÍSTICA}

“'Línguas’ são invenções políticas e disciplinares” (MOITA LOPES, 2018: 89), devendo, portanto, ser sempre glosadas, o que coloca suas existências sob suspeita. Colorir um estado-nação em um mapa com uma língua é igual a forjar um sentido de pertencimento. Ambos os processos se valem de interesses políticos e econômicos, operando performativamente na conceitualização daquilo que chamamos "língua". Da mesma forma como um ideal essencialista de uma "língua" recruta a invenção de um estado-nação como uma comunidade imaginada (e vice-versa) (ANDERSON, 1983), uma "língua" também recruta igualmente ideais identitários essencialistas para os habitantes de um estado-nação. Subjaz a tal concepção uma ideologia linguística, i.e. crenças acerca das "línguas" que orientam o que elas são e seus usos (KROSKRITY, 2000; 2004), operando segundo noções de clareza, exatidão, territorialidade, representação do mundo, neutralidade, e descorporificação (MOITA LOPES, 2018). Uma compreensão dessa natureza, que aborda "línguas" como pacotes bem embrulhados e amarrados, só se aplicaria a idealizações como dicionários ou livros de gramática. Tais parâmetros não acolhem fenômenos semióticos como o da circulação viral de Anitta e do Team Aspo.

Assim, vários pesquisadores (MAKONI; PENNYCOOK, 2007; BPLOMMAERT; RAMPTON, 2011; HELLER, 2007, 2010; MOITA LOPES, 2013, 2018, por exemplo) têm argumentado em favor da necessidade de desinventar o conceito de 'língua' e fazêlo operar em outros termos. Argumentam que é necessário pensar 'línguas' em relação à comunicação entre pessoas situadas em práticas, e não como algo que paira acima delas (MAKONI; PENNYCOOK, 2007: ix). Assim, a "língua" tem que ser entendida como um fazer performativo, um constante jogo de "como-se", i.e. de ficcionalização, que na prática situada faz surgir, por meio de repetições e mudanças, modos performativos de construir significados que não pre-existem ao fazer (PENNYCOOK, 2010). 
Essa visão é informada pelo trabalho de Butler (1990), para quem a natureza performativa do significado pode explicar como o ser não pre-existe ao fazer. É na ação situada sob um enquadre regularizado (por meio de repetição) e, ao mesmo tempo, driblando tais regularizações (por meio de subversões e mudanças), que significados alternativos são forjados. É também assim que Butler (1990) igualmente explica os significados de gênero e sexualidade como efeitos dos sentidos que produzimos aqui e ali sob a matriz da heteronormatividade, os quais, como as "línguas", terminam adquirindo um sentido de substância e estabilidade pela repetição. Podemos atribuir, assim, o mesmo status de ficção do "como-se" das "línguas" ao gênero e à sexualidade - como de fato a encenação queer dos meninos filipinos convoca. O mundo queer (RUTI, 2017; BERNINI, 2015; HALBERSTAM, 2011) é fundamentalmente um mundo do "como-se", que chama atenção para a natureza sempre performativa do gênero e da sexualidade e, no caso em tela, do que chamamos de "língua portuguesa".

A ideologia linguística que podemos forjar a partir do diálogo viral entre os vídeos de Anitta e do Team ASPO é crítica de uma ideia de "língua" como "um artifício para imaginar comunidade" e "como um patrimônio compartilhado" (PRATT, 1987, p. 50). Prestigiando uma linguística dos contatos (PRATT, 1987) e das fronteiras (físicas e virtuais), tal ideologia vê no hibridismo e nas misturas uma força constitutiva central. Esse aspecto é típico de um mundo da superdiversidade no qual a conceitualização tradicional de "língua" é destronada em favor da ideia de mesclagem de recursos semióticos de natureza diversa, distribuídos desigualmente na vida social e que utilizamos uns com os outros ao agir no mundo performativamente aqui e ali (BLOMMAERT, 2010; HELLER, 2010).

Essa forma de abordar a linguagem opera na contramão de uma ideologia linguística referencialista, segundo a qual a "língua" representa o mundo à volta de falantes, escritore/as etc. Na visão performativa que exploramos em companhia de Anitta e Team ASPO, os significados não pre-existem aos usos. Assim, referenciar o mundo é somente uma das possibilidades de forjar significados. Nosso/as parceiro/as de viagens textuais nos mostram que é mais operacional pensar em como construímos significados ao indexar discursos (conhecimentos, valores, e ideologias) que vão recontextualizando e metamorfoseando performativamente nossos textos (BLOMMAERT, 2010). Esta visão também colabora para pensar a linguagem e a construção de significado em fluxo movimentado por processos incessantes de entextualização e indexicalidade.

Vista pelas lentes de uma outra ideologia linguística, a trajetória do 'Show das Poderosas' acima discutida ganha nuances adicionais. Se pensarmos no deslocamento do "português brasileiro" para uma região inesperada, a ilha de Cebu, vemos não apenas um redirecionamento de rotas tradicionais seguidas por artefatos culturais, do sentido "nortesul" para o sentido "sul-sul", mas também uma problematização da projeção dessas divisões. Além disso, o "português" reaparece de repente na Ásia, para onde foi levado durante o chamado período das Grandes Navegações, reciclando um tipo de globalização completamente diferente do desenvolvido pelos portugueses nos séculos XV-XVIII. As "navegações" que a web agora propicia flui em uma globalização desterritorializada, que se expande em uma variedade de trilhas incertas. 
Se o funk brasileiro de Anitta tivesse irrompido em Moçambique ou Angola ou no chamado mundo do português global (MOITA LOPES, 2018), não causaria estranhamento por conta da influência da mídia brasileira nesses espaços, incluindo o próprio antigo colonizador, Portugal. As Filipinas como destino do "Show da poderosas" é bastante singular, pois quebra expectativas quanto a sua circulação e quanto ao papel que o "português" exerce no mundo.

Em relação a esse aspecto, a lógica do "como-se" parece também incidir sobre o a atividade lúdica de mimesis que envolve o uso do "português" por Royce. Imitações dessa natureza são típicas de performances de drag queens pelo mundo afora. Entretanto, não é usual vermos o 'português' do Brasil nessa função que geralmente cabe ao "inglês" como "língua franca internacional" ou "língua da globalização". No caso de Royce Cherdan Lee, porém, tal situação não causa espanto, pois uma rápida pesquisa na Internet mostra que usos transidiomáticos (JACQUEMET, 2005) fazem parte de seu cotidiano. Em sua página do Facebook, por exemplo, ele parabeniza seu namorado em "inglês", "filipino" (ou "cebuano") e gírias e emoticoms correntes na Internet :

\begin{abstract}
A very Happy Birthday to my Handsome/Humble co-Auditionee in PBB 737, my Boy Friend Jan Cee! Emoticon kiss (Soon to be Artista) Thank you very much so much for being a nice friend and also for believing in my Talent. Hehehe! Salamat jud kaayog dako sa imong gihatag nga oras sa katong panahon nga nag linya tag pila ka oras para sa atong pangandoy og sa pagkig cheka about sa imong life. Hehehe! May the god bless you always and your family. Stay healthy, good boy and of course handsome. Hehe! I miss you and see you around. Mwuahhugz! xoxo c:
\end{abstract}

Essa prática de transidiomaticidade não causa espécie uma vez que, nas Filipinas, além das duas "línguas" oficiais, "filipino" e "inglês", 19 outras "línguas" são reconhecidas no país. Tal vida transidiomática pode explicar, assim, o aparecimento de mais uma - o "português". Um tal "estado-nação" construído em meio a tantos recursos semióticos, e no qual a entidade "língua" é descentrada, é terreno fértil para acolher outros recursos.

\title{
5 IDEOLOGIAS LINGUÍSTICAS E METAPRAGMÁTICAS TRANSLOCAIS
}

Nosso empenho em acompanhar a trajetória textual do vídeo de Anitta para as Filipinas, e sua re-entextualização/resemiotização, indica a necessidade de operarmos com uma lógica de mobilidade que dê conta dos usos de linguagem em nossos tempos de fluxos. A fluidez acentuada da atualidade, que possibilita imaginações inovadoras sobre nossas vidas sociais (inclusive sobre "línguas" e linguagem), parece visibilizar a natureza 'como-se' do fenômeno que chamamos "língua" e "categorias identitárias", (como homens, mulheres, homossexuais, heterossexuais etc). Tal natureza, como argumentamos, é performativa e se vale dos recursos semióticos e corpóreos dos quais lançamos mão aqui e ali. Especialmente, cabe salientar que as ideologias linguísticas tradicionais - em razão de sua matriz autônoma, respresentacionista, estruturalista e objetivista - não dialogam com uma perspectiva segundo a qual corpo, "língua" e linguagem operam dentro de uma mesma lógica: a do "como-se" ou da performatividade. 
Assim, o número infinito de textos em movimento sob os quais vivemos agora torna possível, em nossos processos potentes de reentextualização, o afastamento de concepções estruturalistas e referencialistas, em direção a outras que prestigiam a mobilidade indexical em viagens textuais. Dessa forma, é possível entender não apenas como modelos de comunicabilidade são concebidos e que trajetórias ensejam em seus momentos instanciados de "estabilidade", mas também como operam as projeções metapragmáticas translocais que tais "estabilidades" provocam. As projeções metapragmáticas do vídeo de Anitta e a do grupo Team ASPO forjam significados translocais no chamado sul global, envolvendo uma produtividade semiótica vigorosa. É claro que as interpretações aqui apontadas são passíveis de refutação por outro/as leitore/as, analistas ou interlocutore/as, indicando como os mesmos índices podem apontar para compreensões e discursos diversos. Tal característica é principalmente intensificada se considerarmos "a temporalidade reversível e multifacetada da comunicação na Internet” (BRIGGS, 2007, p. 556). Em tais circunstâncias, o foco em indexicalidades-em-movimento fornece uma bússola para o trânsito por territórios instáveis.

\section{REFERÊNCIAS}

ANDERSON, B. Imagined communities. London: Verso, 1983.

APPADURAI, A. (Org.). Globalization. London: Duke University Press, 2001.

BARNARD, I. Queer race: cultural interventions in the racial politics of queer theory. Nova York: Peter Lang, 2004.

BAKHTIN, M. The dialogical imagination. Michael Holquist (Org.). Austin: University of Texas Press, 1981.

BAUMAN, R.; BRIGGS, C. Poetics and performance as critical perspectives on language and social life. Annual Review of Anthropology, v.19, p. 59-88, 1990.

BAUMAN, R.; BRIGGS, C. Voices of modernity. Language ideologies and the politics of inequality. Cambridge: Cambridge University Press, 2003.

BAYNHAM, M. Towards performative sociolinguistics? On coming out and staying out in narrative and interaction. Trabalho apresentado no Congresso Sociolinguistics of Globalization, University of HongKong, mimeo, 2015.

BERNINI, L. Apocalipsis queer. Elementos de teoría antisocial. Barcelona: Egales, 2015.

BLOMMAERT, J. The sociolinguistics of globalization. Cambridge: Cambridge University Press. 2010.

BLOMMAERT, J; RAMPTON, B. Language and superdiversity: a position paper. Working papers in urban language \& literacies, v.70, n.14, p. 1-22, 2011.

BRIGGS, C. L. Anthropology, interviewing, and communicability in contemporary society. Current Anthropology, vol. 48, n. 4, p. 551-561, 2007.

BUTLER, J. Gender Trouble: Feminism and the subversion of identity. New York: Routledge, 1990.

Excitable speech. A politics of the performative. New York: Routledge, 1997.

COUPLAND, N. Style: language variation and identity. New York: Cambridge University Press, 2007.

COUPLAND, N.; GARRET, P.; WILLIAMS, A. Narrative demands, cultural performance and evaluation: teenage boys' stories for their age-peers. In: THORNBORROW, J.; COATES, J. (Org.). The sociolinguistics of narrative. Amsterdam: John Benjamins, 2005, p. 67-88.

DELEUZE, G. Difference and Repetition. London: Continuum, 1968/2004.

DERRIDA, J. Gramatologia. São Paulo: Editora Perspectiva, 1967/2013.

FABRÍCIO, B. F. The empire blogs back: gendered and sexualized cultural 'others'in superdiversified digital trajectories. Discourse, Context \& Media. Special Issue, v. 4, n. 5, p. 7-18, 2014. 
Policing the borderland in a digital lusophone territory: the pragmatics of entextualization. In: MOITA LOPES, L. P. (Org.). Global Portuguese. Linguistic ideologies in late modernity. Nova York: Routledge, 2018.

HARDT, M.; NEGRI, A. Multidão. Trad. Clóvis Marques. Rio de Janeiro: Record, 2005.

HALBERSTAM, J. The queer art of failure. Londres: Durham University Press, 2011.

HELLER, M. The future of 'bilingualism'. In: HELLER, M. (Org.). Bilingualism: a social approach. Nova York: Palgrave Macmillan, 2007, p. 340-345.

Language as resource in the globalized new economy. In: COUPLAND, N. (Org.). The handbook of language and globalization. Oxford: Wiley-Blackwell, 2010, p. 349-365.

JACQUEMET, M. Transidiomatic practices: language and power in the age of globalization. Language and Communication, v. 25, n. 3, p. 257-277, 2005.

KROSKRITY, P. Regimenting languages: language ideological perspectives. In: (Org.). Regimes of language: Ideologies, politics and identities. Santa Fe: School of American Research Press, 2000, p. 134.

Language ideologies. In: DURANTI, A. (Org.). A companion to linguistic anthropology. Oxford: Blackwell, 2004, p. 496-517.

LOPES, A. C. Funk-se quem quiser. No batidão negro da cidade carioca. Rio de Janeiro: Bom Texto / FAPERJ, 2011

MAKONI, S.; PENNYCOOK, A. (Org.). Disinventing and reconstituting languages. Clevendon: Multilingual Matters, 2007.

MIGNOLO, W. D. Local histories/ global designs: Coloniality, subaltern knowledges and border thinking. Princeton: Princeton University Press, 2000.

MOITA LOPES, L. P. Introduction: Linguistic ideology: how Portuguese is being discursively constructed in late modernity. In: (Org.). Global Portuguese. Linguistic ideologies in late modernity. Nova York: Routledge, 2018, p. 1- 26.

Como e por que teorizar o português como recurso comunicativo em sociedades porosas em tempos híbridos de globalização cultural. In: MOITA LOPES, L. P. O português no século XXI. Cenário geopolítico e sociolinguístico. São Paulo: Parábola, 2013, p. 101-119.

MOITA LOPES, L. P.; BAYNHAM, M. (Org.). Introduction. Meaning making in the periphery. AILA Review, vol. 30, p. v-Xiii, 2018.

PENNYCOOK, A. Global Englishes and transcultural flows. Londres: Routledge, 2007.

Language as a local practice. New York: Routledge, 2010.

Language and mobility. Unexpected places. Bristol: Multilingual Matters, 2012.

PRATT, M. L. Linguistic utopias. In: FABB, N.; ATTRIDGE, D.; DURANTI, A.; MACCABE, C. (Org.). The linguistics of writing: arguments between language and literature. Manchester: Manchester University Press, 1987, p. 48-66.

RUTI, M. The ethics of opting out. Queer theory's defiant subjects. New York: Columbia University Press, 2017.

SANTOS, M. Por uma outra globalização. Rio de Janeiro: Record, 2000.

SHUSTERMAN, R. Performing live: Aesthetic alternatives for the ends of art. Ithaca: Cornel University Press, 2000.

SULLIVAN, N. A critical introduction to queer theory. Nova York: New York University Press, 2003. SILVERSTEIN, M.; URBAN, G. Natural histories of discourse. Chicago: The University of Chicago Press, 1996.

THRIFT, N. Non-representational theory. Space, Politics, Affect. Londres: Routledge, 2008.

TAYLOR, Y. The 'outness' of queer: class and sexual intersections. In: BROWNE, K.; NASH, C. J.

(Org.). Queer methods and methodologies. Intersecting queer theories and social sciences research. New York: Routledge, 2016, p. 69-84.

VARIS, P; BLOMMAERT, J. Conviviality and collectives on social media: Virality, memes, and new social structures. Tilburg Papers in Culture Studies, Tilburg University, n.108, p. 1-21, 2014.

VENN, C. Occidentalism: Modernity and subjectivity. London: Sage, 2000.

VERTOVEC, S. Super-diversity and its implications. Ethnic and Racial Studies, v. 30, n. 6, p. $1004-$ 1054, 2007.

MOITA LOPES, Luiz Paulo da; FABRÍCIO, Branca Falabella. Viagem textual pelo sul global: ideologias linguísticas queer e metapragmáticas translocais. Linguagem em (Dis)curso - LemD, Tubarão, SC, v. 18, n. 3, p. 759-784, set./dez. 2018. 
Show Das Poderosas - Anitta

Prepara, que agora é a hora

Do show das poderosas

Que descem e rebolam

Afrontam as fogosas

Só as que incomodam

Expulsam as invejosas

Que ficam de cara quando toca

Prepara

Se não tá mais à vontade, sai por onde entrei

Quando começo a dançar, eu te enlouqueço, eu sei

Meu exército é pesado, e a gente tem poder

Ameaça coisas do tipo: Você!

Vai!

Solta o som, que é pra me ver dançando

Até você vai ficar babando

Para o baile pra me ver dançando

Chama atenção à toa

Perde a linha, fica louca

Solta o som, que é pra me ver dançando

Até você vai ficar babando

Para o baile pra me ver dançando

Chama atenção à toa

Perde a linha, fica louca

Recebido em: 05/07/18. Aprovado em: 29/09/18.

Title: Textual travel by Global South: queer linguistic ideologies and translocal metapragmatics

Authors: Luiz Paulo da Moita Lopes; Branca Falabella Fabrício

Abstract: Based on the analysis of the re-entextualization of a Brazilian professional funk video into a homemade video in the Philippines, made by queer young men, this article discusses the linguistic ideology and the meta-pragamatic projections that such a textual trajectory invokes. Besides being informed by queer theories, the study also relies on the theoretic-analytical constructs of indexicality, circulation of discourses, fields of communicability and performativity. It argues that the linguistic ideology mobilized in the focused re-entextualization process is different from traditional representational and modernist ideologies, as it points to performative views of languages and of participants' bodies. Such an ideology is forged by means of translocal meta-pragmatics that project a logic of an as-if social world. Investigating it implies the observation of in-transitindexicalities.

Key-words: Re-entextualization. Indexicality. Linguistic ideology. Translocality. Queer theories. 
Título: Viaje textual por el Sur Global: ideologías lingüísticas queer y meta-pragmáticas translocales

Autores: Luiz Paulo da Moita Lopes; Branca Falabella Fabrício

Resumen: Basado en el análisis de la retextualización de un vídeo profesional brasileño de funk en un vídeo casero en Filipinas, hecha por niños queer, este artículo discute la ideología lingüística y las proyecciones meta-pragmáticas translocales que tal trayectoria textual justifica. Pautado en teorizaciones queer, el trabajo explora ese movimiento translocal utilizando los constructos teórico-analíticos de indexicalidad, circulación de discursos, campos de comunicabilidad y performatividad. Argumenta que la ideología lingüística movilizada en el proceso de retextualización enfocado se diferencia de las tradicionales ideologías lingüísticas representacionales y modernistas, cuando apunta para visiones performativas de lenguas y de los cuerpos de los participantes. Tal ideología es compuesta por medio de meta-pragmáticas translocales que proyectan una lógica de un mundo social como-se. Investigarla implica la observación de indexicalidades-en-movimiento.

AGRADECIMENTOS

Somos gratos ao CNPq pelas bolsas de produtividade em pesquisa outorgadas a Luiz Paulo da Moita Lopes (CNPq 302935/2017-7) - ORCID ID https://orcid.org/00000002-3829-9824 - e a Branca Falabella Fabrício (CNPq 311578/2016-0) - ORCID ID https://orcid.org/0000-0003-0006-9924.

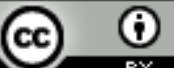

Este texto está licenciado com uma Licença Creative Commons Atribuição 4.0 Internacional.

MOITA LOPES, Luiz Paulo da; FABRÍCIO, Branca Falabella. Viagem textual pelo sul global: ideologias linguísticas queer e metapragmáticas translocais. Linguagem em (Dis)curso - LemD, Tubarão, SC, v. 18, n. 3, p. 759-784, set./dez. 2018. 